\title{
LAS OBRAS DE ARTE AL SERVICIO DEL CINE
}

\author{
Clementina Calero Ruiz* \\ Universidad de La Laguna
}

\section{RESUMEN}

Las obras de arte toman el poder en el cine, donde pinturas y esculturas se convierten en fuente de inspiración para algunas de las películas más célebres de la gran pantalla, viéndose reflejadas en los carteles que las publicitan, en los programas de mano que las anuncian o en algunas escenas. Y no solo es que utilicen o tomen prestadas algunas de las obras más célebres de la historia del arte, sino que, en ocasiones, también se han inspirado en obras artísticas para hacer reales las historias que cuentan.

Palabras Clave: historia del arte y cine, tradición clásica en el arte, arte antiguo, arte moderno.

WORKS OF ART

AT THE SERVICE OF CINEMA

\section{Abstract}

Artworks take power in the cinema, where paintings and sculptures become a source of inspiration for some of the most famous films on the big screen. We see this reflected in the posters that advertise the movies, in the hand programmes that announce them, or in some scenes. But not only are these distinguished artworks in art history used or borrowed, but sometimes, they have also been inspired by artistic works to make their story reliable and true.

Keywords: Art History and Cinema, Classical Tradition in Art, Ancient Art, Modern Art. 
Las obras de arte toman el poder en el cine, convirtiéndose en fuente de inspiración para algunas de las películas más célebres de la gran pantalla, viéndose reflejadas en los carteles que las publicitan, en los programas de mano que las anuncian y les sirven de reclamo o en algunas escenas. Y no solo es que utilicen o tomen prestadas algunas de las obras más célebres de la historia del arte, sino que en ocasiones también se han inspirado en ellas haciéndolas que "respiren y vivan» en las historias que cuentan. Y es que el cine, como arte totalizador, tiene la capacidad de referenciar a todas las demás disciplinas, además de autorreferenciarse, convirtiéndose en un magnífico vehículo de expresión. De todos es sabido el alto poder de sugestión que tiene la imagen ${ }^{1}$, de modo que, de esta manera, se abre un amplio abanico de posibilidades a la hora de captar nuevos públicos².

$\mathrm{Y}$, qué imagen puede ser más sugerente que la de Venus ${ }^{3}$-Afrodita para los griegos, alabada por Homero-, cuyo erotismo se basa en el hecho de desvestirse y mostrarse desnuda:

Voy a cantar a la augusta, a la coronada de oro, a la hermosa Afrodita, que tutela las murallas de toda la marinera Chipre, donde el húmedo ímpetu del soplador Céfiro la llevó entre blanda espuma a través del oleaje de la mar resonante. Las Horas de áureas diademas la acogieron de buen grado, la ataviaron con divinos vestidos y sobre su cabeza inmortal pusieron una corona bien trabajada, áurea y hermosa, mientras que colocaban en sus perforados lóbulos flores de oricalco y de oro precioso. Rodearon su delicado cuello y su pecho, blanco como la plata, con collares como los que ellas mismas se ponen cuando van al placentero coro de los dioses y a las moradas de su padre (Zeus) ${ }^{4}$.

La Afrodita Anadyomene, la que surge de las aguas y que Apeles de Cos pintara a finales del siglo iv a.C. ${ }^{5}$, donde aquélla se nos presentaba desnuda, plena de gracia y encanto - charis- escurriendo su larga cabellera ${ }^{6}$. La pintura no se ha conservado, pero sí el relieve que representa su nacimiento en el célebre Trono Ludovici

* Profesora titular de Historia del Arte Moderno, Facultad de Humanidades, Departamento de Historia del Arte y Filosofía, Universidad de La Laguna. Edificio Departamental de Geografía e Historia, Campus de Guajara, s/n, San Cristóbal de La Laguna, 38071. Correo electrónico: ccalero@ull.edu.es ORCID: 0000-0002-0626-8441. Academia.edu: https://ull.academia.edu/ClementinaCaleroRuiz.

${ }^{1}$ Balló, Jordi (2000): Imágenes del silencio. Los motivos visuales en el cine, Barcelona, Editorial Anagrama, pp. 11-20.

2 Ríos Moyano, Sonia y Escalera Pérez, Reyes: «El arte en el cine y su uso como ampliación del conocimiento del hecho artístico». https://dialnet.unirioja.es/servlet/articulo?codigo $=4849546$. [Consultado el 12/5/2020).

${ }^{3}$ Perea, Sabino (1999): El sexo divino. Dioses hermafroditas, bisexuales y travestidos en la Antigüedad clásica, Madrid, Alderabán Ed., pp. 55-57

${ }^{4}$ Himno homérico vi a Afrodita, siglo vir a.C.

5 Pollit, J.J. (1984): Arte y experiencia en la Grecia clásica, Bilbao, Xarait Ediciones, p. 139.

6 Wind, Edgar (1998): "Apéndice 5: La concha de Afrodita», en Los misterios paganos del Renacimiento. Madrid, Alianza Editorial, pp. 259-261. 

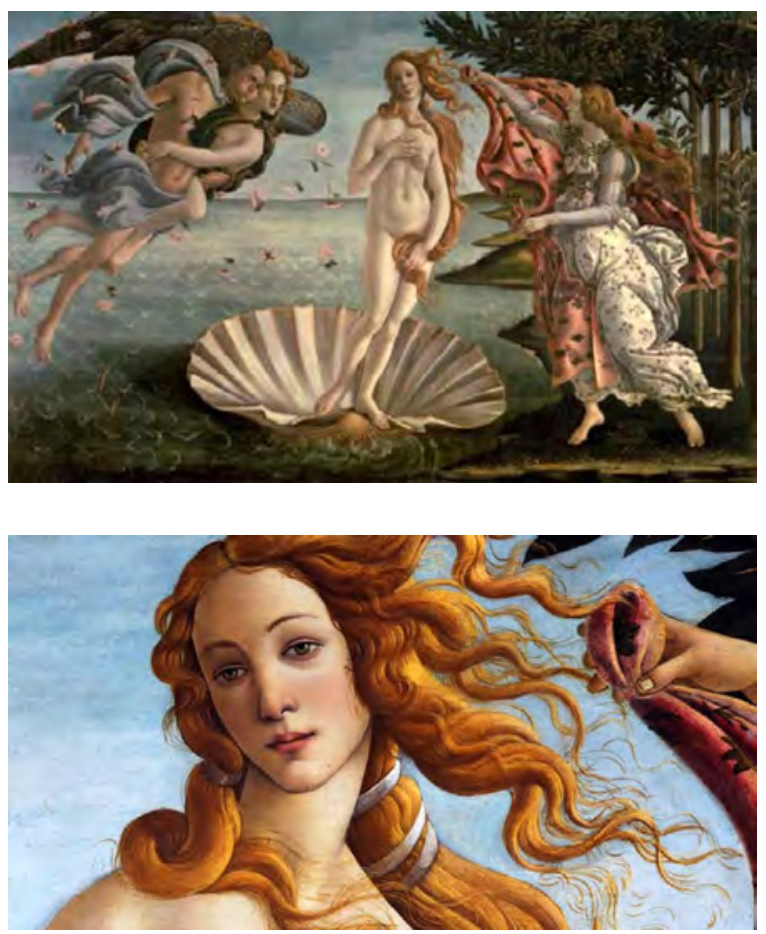

Foto 1. Nacimiento de Venus, Sandro Botticelli (1482-85). Galería de los Uffizi, Florencia (Italia).

(c. 460 a.C.), donde la diosa de la belleza es izada por dos figuras femeninas, que se apresuran a tapar su desnudez con una delicada túnica que deja translucir parte de su cuerpo. La Venus púdica, que se envuelve literalmente con los brazos para elevarse sobre las olas y que pintara Sandro Botticelli [foto 1] en la segunda mitad del siglo Xv, entre 1482 y $1485^{7}$. La estilizada belleza de Venus, con sus largos y ondulados cabellos rubios movidos por Céfiro - dios del viento- y Cloris, llega a la costa de Chipre, donde la espera la Hora de la Primavera para cubrirla con un manto de flores $^{8}$. La idea para el cuadro se la proporcionó Angelo Poliziano, el poeta amigo de Lorenzo de Médici, cuyos versos describen las fiestas, los carros triunfales y las arquitecturas en su obra Stanze per la giostra (Estancias para el torneo):

7 Checa, Fernando (mayo 2020): «Sandro Botticelli. Belleza y patetismo», Descubrir el Arte, año xxiı, n. ${ }^{\circ} 255$. pp. 16-17.

8 Boccaccio, Giovanni (2008). Los quince libros de la Genealogía de los dioses paganos. Introducción, traducción directa del Laurentianus Plut. 52.9, notas e índices de M. ${ }^{a}$ Consuelo Álvarez y Rosa M. ${ }^{a}$ Iglesias, Madrid, Centro de Lingüística Aplicada Atenea, pp. 144-146. 

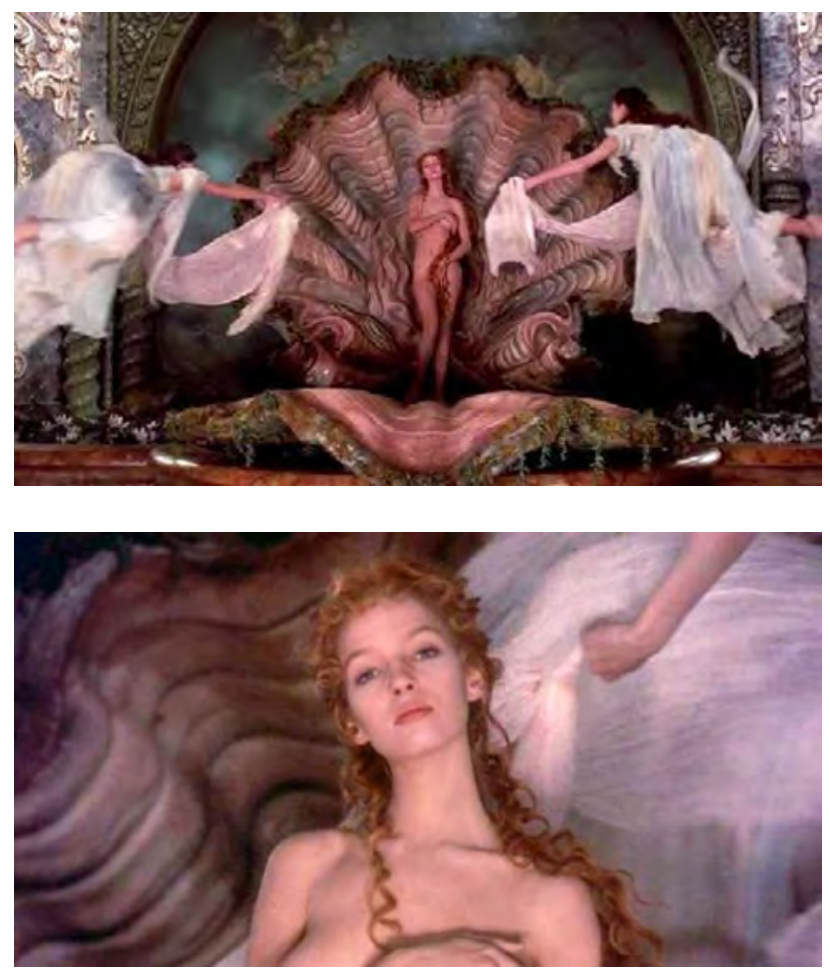

Foto 2. Uma Thurman como Venus. Fotograma de la película Las aventuras del barón Münchausen (Terry Gilliam, 1988).

Sobre el tempestuoso Egeo, en el seno de Tetis acogida, se ve la columna fecunda, bajo el curso variable de los planetas errar sobre la ola, envuelta en la blanca espuma; Y nacida en su seno con gestos graciosos y alegres, una doncella cuyo rostro no es humano, por los lascivos Céfiros impulsada hasta la orilla, va sobre una concha; y parece que el cielo se complace?.

Tanto el poeta como el pintor buscaban evocar el espíritu de la Afrodita Anadyomene de Apeles, de la que se sabía por antiguas descripciones, de modo que,

9 Wind, Edgar (1998): Los misterios paganos del Renacimiento, Madrid, Alianza Editorial, p. 136. «Nel el tempestoso Egeo in grembo a Teti si vede il fusto genitale accolto, sotto diverso volger di pianeti, errar per lónde in bianca schiuma avvolto; E dentro nata in atti vaghi e lieti una doncella non con uman volto, da' Zefiri lascivi spinta a proda, gir sopra un nicchio; e par che 'l ciel ne goda». 

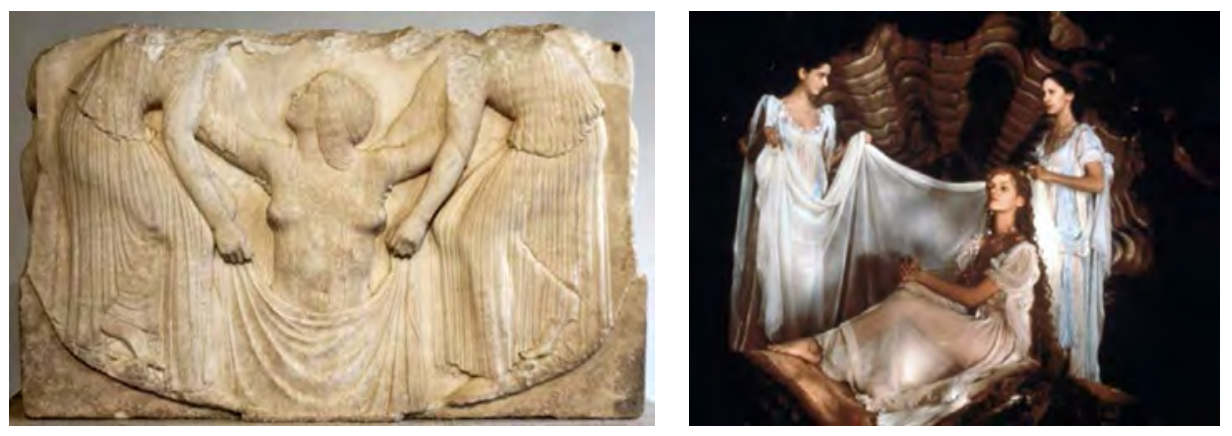

Fotos 3 y 4. Trono Ludovici. c. 460 a.C. Museo de las Termas, Roma (Italia). Fotograma de la película Las aventuras del barón Münchausen (Terry Gilliam, 1988).

más allá de su carácter poético y didáctico, la pintura de Botticelli debe, por tanto, ser clasificada entre aquellas tentativas de resucitar lo antiguo, de hacer resurgir ante los ojos del espectador la visión de una obra perdida de la Antigüedad ${ }^{10}$.

El cuadro ha sido recreado en una escena de la película Las aventuras del barón Münchausen (The Adventures of Baron Münchausen, Terry Gilliam, 1988), donde Uma Thurman da vida a la Venus botticelliana [foto 2]. El barón, tras escapar de la Luna, regresa a la Tierra, aterrizando en la morada del dios Vulcano. El dios los recibe con cortesía, hasta que aparece en escena su esposa Venus (Uma Thurman) emergiendo del mar dentro de una concha y saludando a los presentes con un insinuante hello, que acaba con la hospitalidad de Vulcano ${ }^{11}$, que termina expulsando al barón y a sus acompañantes -Sally y a su antiguo socio Berthold- hacia los mares del sur. A la hora de componer esta escena, se han recreado dos obras a un tiempo; la del Nacimiento de Venus de Botticelli, que es obvia, pero también el relieve del Trono Ludovici [fotos 3 y 4], donde las jóvenes que asisten a Venus se apresuran a taparla.

No obstante, Terry Gilliam ya había utilizado la pintura del maestro florentino en Dancing Venus, un corto animado perteneciente a Monty Python's Flying Circus, donde mediante su técnica de animación de corte, hacía bailar disparatadamente a la diosa, que terminaba perdiendo el equilibrio y caía al mar. El primer

${ }^{10}$ Idem, p. 132.

${ }^{11}$ Dunn Mascetti, Manuela (1990): Diosas. La canción de Eva. El renacimiento del culto a lo femenino, Barcelona, Robinbook/Círculo de Lectores, p. 117. La brusca reacción de Vulcano ante la aparición de su esposa en la escena puede deberse a que ésta, según la mitología clásica, «llevaba un ceñidor mágico que hacía que quienes la vieran se enamoraran inmediatamente de ella. Este don la hacía muy impopular entre las otras Diosas del Olimpo, que sentían celos de su posición [...]. Ella tentaba a hombres y dioses por igual en su lecho de rosas, en cuanto su marido se daba media vuelta». 


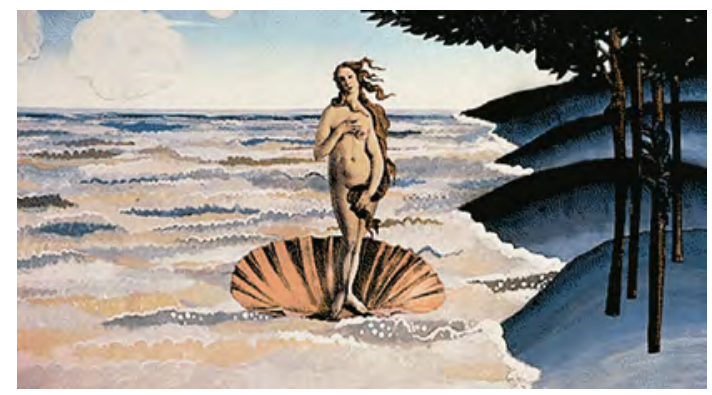

Foto 5. Terry Gilliam, Dancing Venus, 1969.

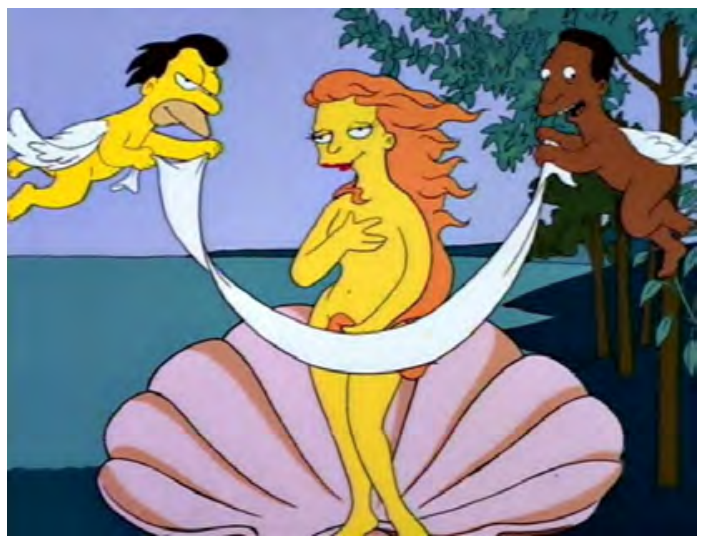

Foto 6. Margo Zavala como la Venus de Botticelli, en Los Simpsons.

episodio fue emitido por la BBC el 5 de octubre de 1969, y estuvo en antena hasta 1974 [foto 5].

De la misma manera fue recreado en el 9. ${ }^{\circ}$ episodio, de la $5 .^{a}$ temporada de Los Simpsons, donde Margo Zavala -en versión inglesa Mindy Simmons- se presenta ante Homer como su nueva compañera de trabajo, y éste, al imaginársela desnuda sobre una venera, cae rendido a sus pies. A su lado sus amigos Lenn y Carl, como puttis alados, sujetan un lienzo tapando su desnudez [foto 6].

En 1993 será Carla Bruni la que adopte la pose de la Venus botticelliana, para el objetivo fotográfico de Michel Comte. La foto en blanco y negro salió a subasta en la casa Christie's de Nueva York, formando parte de un lote de fotografías del siglo xx de Gert Elfering, y acabó vendiéndose a un coleccionista de arte chino por 91000 dólares. Y también la actriz estadounidense Julia Roberts se convirtió en la Venus de Botticelli en el año 2010, para un anuncio publicitario de la marca italiana de café Lavazza. Vestida para la ocasión con un vaporoso traje blanco y con su larga 


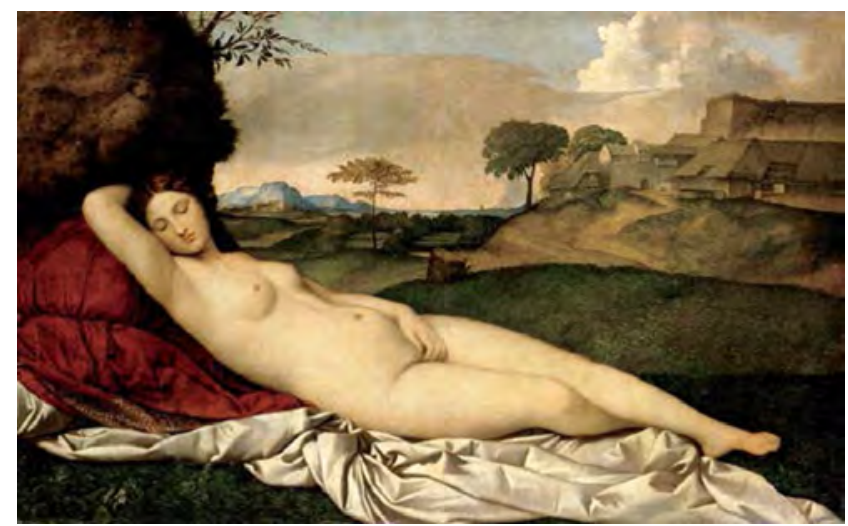

Fotos 7. Giorgione: Venus dormida, Gemäldegalerie Alte Meister, Dresde (Alemania).

melena ondulada, la artista posaba sobre una concha en un plató que simulaba el taller del pintor toscano. Su rostro, en principio serio, esbozaba la sonrisa que la ha hecho famosa cuando le acercaban una taza de café; una sonrisa y un guiño de ojos que costaron nada menos que la suma de 1,2 millones de euros. Hasta Lady Gaga cayó rendida a los pies de la deidad y la rememoró en su álbum Artpop. Aunque la evocación más famosa de la Venus emergente, aunque no la del cuadro, la interpretó Úrsula Andress en la película Agente 007 contra el Dr. No (Dr. No, Terence Young, 1962) en la escena en la que aquélla aparecía cual Venus Anadyomene ante la atónita mirada del agente secreto, papel interpretado por Sean Connery.

La otra versión de Venus nos la presenta recostada, desnuda o semidesnuda, fórmula que se asienta a lo largo del siglo xvı. Como señala Miguel Ángel Elvira, «un icono profano para quien encarga la imagen, y un verdadero canto a la belleza para quien la realiza» ${ }^{12}$. Para Kenneth Clark, la Venus de Giorgione no es antigua, «es tan clásica como cualquier desnudo de la Antigüedad»; la diosa duerme despreocupada, sin importarle su desnudez, es una venus celestial, pero la de Urbino de Tiziano es otra cosa: «Casi no necesitamos que los ojos cerrados de Giorgione y la mirada de Tiziano señalen la diferencia entre ambas». La primera posa relajada, pero la segunda con su mirada nos invita a participar en la acción ${ }^{13}$.

La Venus dormida [foto 7], iniciada por Giorgione y acabada por un joven Tiziano en 1510, que reposa plácidamente sobre un fondo de paisaje, elevándose

12 Elvira Barba, Miguel Ángel (2008): Arte y mito. Manual de iconografía clásica, Madrid, Silex, p. 238.

${ }_{13}$ Clark, Kenneth (1981): El desnudo. Un estudio de la forma ideal, Madrid, Alianza Forma, pp. 118-119. 


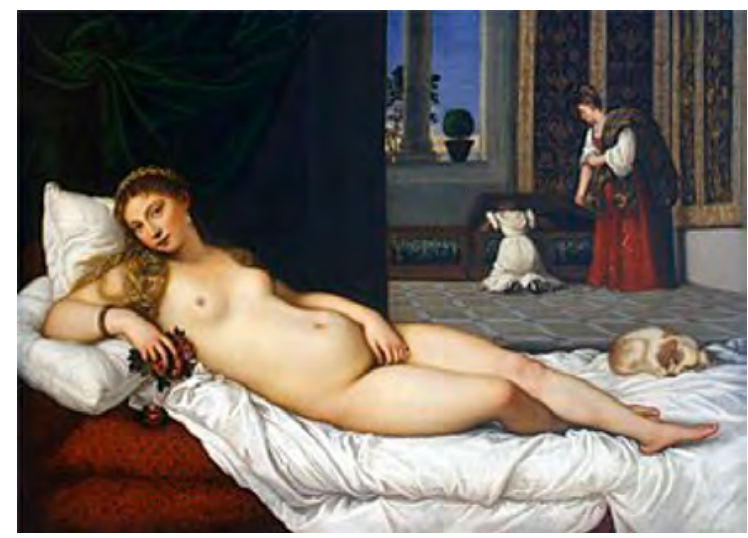

Foto 8. Tiziano: Venus de Urbino (1538). Galería de los Uffizi, Florencia (Italia).

por encima de la materia mundana, hasta la bellísima Venus de Urbino $(1538)^{14}$ [foto 8] que pintara Tiziano, concebida como una Venus púdica que tapa su vientre con la mano izquierda, en cuyo dedo meñique luce un anillo, han sido ejecutadas para despertar los sentimientos más naturales. Esta última -en concreto- para que sirva de exemplum a la joven a quien iba destinado el cuadro: Giulia Varano. La pintura, así entendida, se convierte en una especie de manual que adoctrina a las esposas jóvenes respecto a su comportamiento en el matrimonio; por eso a los pies del lecho y como símbolo de la fidelidad conyugal, se coloca un perro. Estas obras, en opinión de Clark, le permitieron a Tiziano "plasmar en el cuadro la admiración que sentía por la extensión de la piel suave, plena y uniformemente iluminada. Pero a pesar de esta complacencia en la carne, las Venus de esta serie no son provocativas ${ }^{15}$, de modo que, si

en Florencia, la Venus Celestial había surgido del mar de la especulación neoplatónica. En Venecia, su hermana nació en un entorno más tangible de yerbas espesas, manantiales agrestes y frondosa floresta; y durante cuatrocientos años, los pintores han reconocido que la Venus Natural es original y esencialmente veneciana ${ }^{16}$.

No obstante, la postura de las venus reclinadas o acostadas tiene su origen en el mundo antiguo, como lo evidencia la Ariadna dormida (o el Sueño de Ariad-

14 Wind, Edgar (1998): «Amor sacro y Amor profano», en Los misterios paganos del Renacimiento, Madrid, Alianza Editorial, pp. 141-142.

${ }_{15}$ Clark, Kenneth (1981): El desnudo. Un estudio de la forma ideal, Madrid, Alianza Editorial, p. 130 .

${ }_{16}$ Idem, p. 121. 


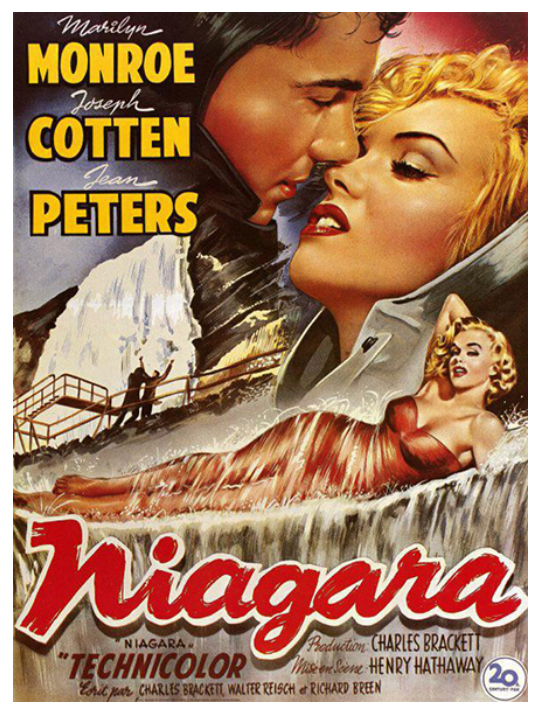

Foto 9. Cartel de la película Niágara (Henry Hathaway, 1953).

$n a)^{17}$, de los Museos Vaticanos, que representa a la princesa cretense descansando después de haber sido abandonada por Teseo en la isla de Naxos, tras haber escapado de Creta y dar muerte al minotauro. El mundo grecorromano capta muy bien las complejas facetas del erotismo: desde la sensualidad a la ironía. Quizás ése fuera el detonante que motivara su elección para el cartel publicitario de la película norteamericana Niágara (Henry Hathaway, 1953) [foto 9], donde una sensual Marilyn Monroe personifica a las cataratas que dan nombre al filme. Curiosamente, y pese a que la actriz no es la protagonista, sino Jean Peters (Polly Cutler), ella acapara todas las miradas, al tiempo que se va forjando el mito de mujer fatal que la acompañará a lo largo de toda su carrera.

Opinamos que la elección de la imagen de Venus no es casual, pues su matrimonio con Vulcano fue ocasión del adulterio de ésta con Marte -además de con Mercurio, Adonis, Poseidón..., entre otros-; viéndose reflejada en Rose Loomis (Marilyn Monroe), que al margen de su matrimonio, tenía relaciones con Patrick (Richard Allan), con quien había proyectado asesinar a su marido George Loomis (Joseph Cotten).

${ }^{17}$ La escultura es una copia hecha por un artista de época antonina (siglo II d.C.), labrada a partir de un original de la Escuela de Pérgamo (siglo III a.C.), que a su vez debió inspirarse en una pintura del templo de Dioniso en Atenas. Ver Bussagli, Marco y Zuffi, Stefano (2001): Arte y erotismo, Milán, Ed. Electa, p. 38. 
El cartel la presenta recostada, según la postura tradicional para este tipo iconográfico, vestida con un sugerente y ceñido traje rojo que, en realidad, no es un traje completo, si exceptuamos la parte superior, pues detrás de la cortina de agua se insinúa la figura desnuda de la actriz, que queda difuminada como si estuviera recostada en el propio borde de la catarata que le da nombre, y cuyas aguas son las que, sinuosamente, dibujan el sugerente ropaje. Es un vestido desnudo; una auténtica dicotomía: estar desnudo y vestido al mismo tiempo ${ }^{18}$. A la postura -ya analizada- le sumamos otra iconografía donde la figura femenina es la representación de fuentes ${ }^{19}$, cascadas o, como en este caso ocurre, cataratas; Marilyn es en sí misma la personificación de las cataratas. De modo que, en este sentido, el agua con una fuerte carga de erotismo bebe del simbolismo de la fuente, presentándose la figura femenina como propiciadora de la fecundidad sexual ${ }^{20}$.

El ejemplo es mucho más evidente en otro cartel [foto 10] donde el color empleado para el cuerpo y traje de la actriz es el azul, claramente identificado con el agua que se precipita al vacío. Al agua, iconográficamente, se la figura como una mujer semidesnuda -como en este caso- con un manto de color cerúleo, semejante al del cielo despejado o el de alta mar -en este caso no se trata de un manto, pero sí se insinúa el ceñido traje, un vestido desnudo-, que desciende desde una roca hacia el mar. Esta solución recuerda los vestidos que en la Antigüedad griega se confeccionaban en la isla de Cos, con un tejido parecido a un velo que dejaba transparentar el cuerpo, y que conocemos como draperie. El draperie nos enseńa sobre el cubrimiento del desnudo en las figuras y sobre los plegamientos de sus vestidos, y se hacía «a partir de unos hábitos húmedos y estrechos que, en consecuencia [...] se adhieren ajustadamente a la piel y al cuerpo, dejando ver su desnudez $»^{21}$. Para Wickelmannm, «tras la bella naturaleza y el noble contorno, esta ciencia es la tercera cualidad que hace superiores las obras de la Antigüedad», siendo una de las características de Parrasio, considerado el mejor escultor griego de su época por lo que al contorno respecta, pues

incluso bajo las vestimentas de las figuras griegas domina, como prioritaria intención del artista, un modélico contorno que muestra, tanto a través del mármol, como a través de un vestido de la isla de Cos, la bella estructura del cuerpo ${ }^{22}$.

18 En el mausoleo del «dintel de los ríos» de Mérida (España), fechado a mediados del siglo III, se representan los ríos Ana y Barraeca, que, a diferencia de otras deidades fluviales que van desnudas o semidesnudas, llevan vestidos desnudos; es decir, las eses labradas sobre las extremidades inferiores simulan las aguas que los visten. Marco Simón, Francisco: «Revve anabaraego y el "dintel de los ríos" de Mérida: ¿̇un ejemplo de disociación divina en el occidente hispano?», https://dialnet.unirioja.es/servlet/articulo?codigo $=6897367$. [Consultado el 8/6/2020].

19 Bussagli, Marco y Zuffi, Stefano (2001): «Bellezas en el baño», en Arte y erotismo, Milán, Ed. Electa, p. 214.

${ }^{20}$ Revilla, Federico (2007): Diccionario de Iconografía y Simbologia (5. ${ }^{a}$ edición ampliada), Madrid, Grandes Temas Cátedra, p. 257.

${ }^{21}$ Winckelmann, Johan Joachim (1987): Reflexiones sobre la imitación del arte griego en la pintura y la escultura, Barcelona, Nexos, p. 35.

22 Idem, p. 32. 


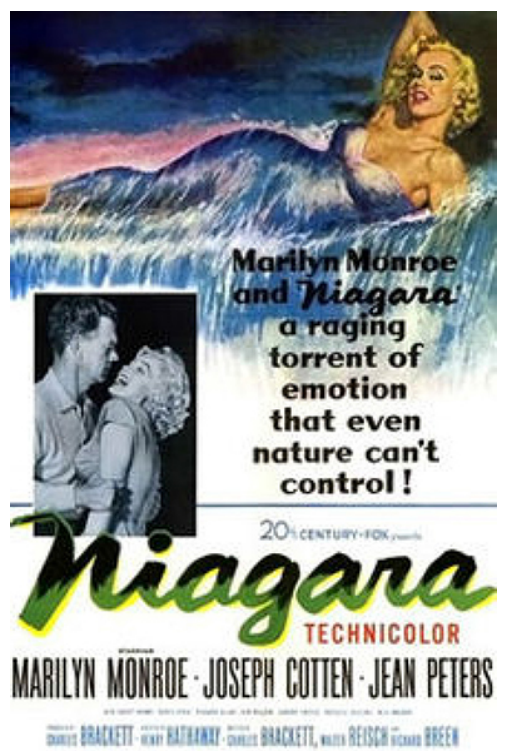

Foto 10. Cartel de la película Niágara (Henry Hathaway, 1953).

La actriz mira hacia afuera, insinuante y con cierto descaro, recordando la mirada de la Maja desnuda de Goya (1795-1800) o la de la Olimpia de Manet (1863). También la Venus del espejo de Velázquez mira al espectador, pero lo hace al contrario, desde dentro del cuadro hacia afuera usando el recurso del espejo ${ }^{23}$ que sostiene Cupido.

Y éste es el puente iconográfico, como lo define Elvira Barba ${ }^{24}$, entre esta tipología y la siguiente, la Venus del espejo de Diego Velázquez (c. 1650) [foto 11], donde se funde la Venus recostada con la que se mira al espejo ${ }^{25}$; una imagen con tradición en la Antigüedad y recuperada en el Renacimiento con un sentido ambivalente, porque el espejo tanto puede aludir a la vanidad como sugerir admiración por la belleza, además de -en este caso concreto- la posibilidad de verle el rostro -aunque difuminado- a la diosa. Para Cesare Ripa, "la Belleza es en sí misma un espejo, en el que cada uno se ve a sí mismo en mejor perfección, como reflejo de la

23 Balló, Jordi (2000): Imágenes del silencio. Los motivos visuales en el cine, Barcelona, Editorial Anagrama, pp. 75-78.

${ }^{24}$ Elvira Barba, Miguel Ángel (2008): Arte y mito. Manual de iconografía clásica, Madrid, Silex, p. 238.

${ }_{25}$ Balló, Jordi (2000): Imágenes del silencio. Los motivos visuales en el cine, Barcelona, Editorial Anagrama, pp. 61-62. 


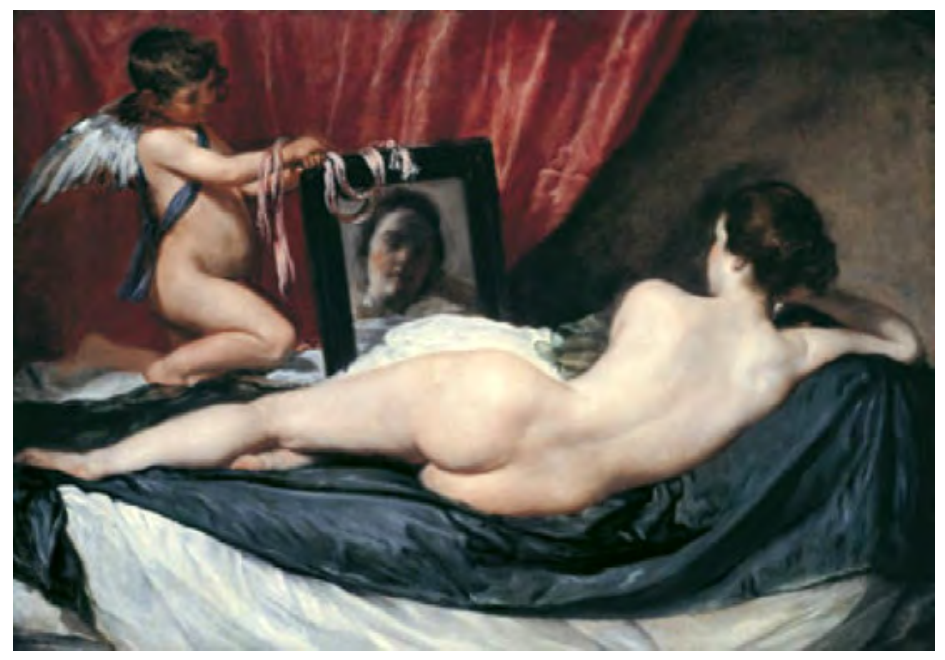

Foto 11. Diego Velázquez: Venus del espejo (1647). National Gallery, Londres (Reino Unido).

Belleza ${ }^{26}$. El pintor sevillano combina en su tela dos temas tradicionales como son el de la Venus ante el espejo con Cupido y Venus tumbada, convirtiéndose en una novedad por usar como centro un espejo, y por mostrar el cuerpo de la diosa de espaldas, y Pedro Almodóvar en su película La piel que habito $(2011)^{27}$ combina de manera magistral ambos temas.

El argumento gira en torno a un renombrado cirujano plástico, el doctor Robert Ledgard (Antonio Banderas), que, tras sufrir un accidente de tráfico que dejó desfigurado el rostro de su esposa Gal -que termina suicidándose-, consigue crear en su laboratorio un tipo de piel que protege frente a las agresiones pero que al mismo tiempo es suave al tacto. Para experimentar su descubrimiento necesita un «ratón de laboratorio humano», y encuentra al candidato perfecto en Vicente, el violador de su hija Norma, a quien -tras múltiples operaciones- transforma en Vera (Elena Anaya). Para López Revuelta, "la piel juega un papel importante, [porque] es la renovación, la sensualidad, la pasión, la venganza... En resumen, la piel y los sen-

${ }^{26}$ Bussagli, Marco y Zuffi, Stefano (2001): «El espejo de mis deseos», en Arte y erotismo, Milán, Ed. Electa, p. 195. Lo specchio dimostra essere la bellezza feminile medesimamente uno specchio, nel quale vedendo ciascuno se stesso in miglior perfettione.

27 Zurian, Francisco A. y Caballero Gálvez, Antonio A.: «Género y cuerpo en construcción. Representación audiovisual de la violencia física y psicológica en La piel que habito (2011)», Printemps 2017, número 11. https://www.researchgate.net/publication/321858144_Genero_y_cuerpo_ en_construccion_Representacion_audiovisual_de_la_violencia_fisica_y_psicologica_en_La_piel_ que_habito_2011. [Consultado el 20/5/2020]. 

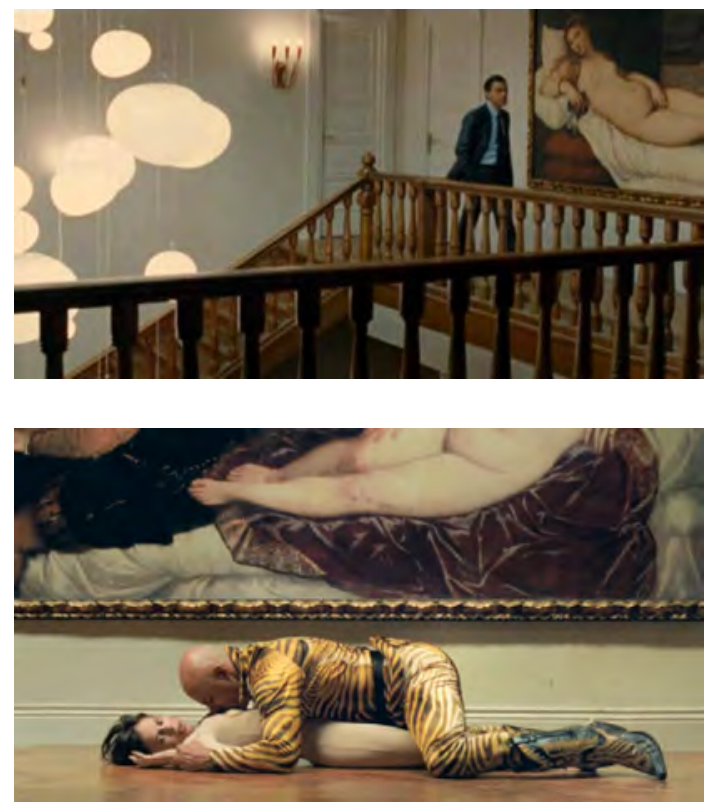

Fotos 12 y 13. Fotogramas de la película La piel que habito (Pedro Almodóvar, 2011).

timientos que provoca ${ }^{28}$. En este sentido, las pinturas de la escuela veneciana y en especial las telas de Tiziano evocan el placer de la belleza, de la contemplación, de la sensualidad..., de modo que no es casual que precisamente en la película aparezcan dos cuadros de este maestro. Uno, la Venus de Urbino, que preside la escalera de la mansión el Cigarral [foto 12], donde el médico reside con Marilia (Marisa Paredes), su ama de llaves; el otro es Venus recreándose con el amor y la música, que está colgado al lado de la puerta que conduce a la habitación donde Vera está recluida, y donde Zeca (Roberto Álamo) la viola [foto 13]. No deja de ser curioso que se haya escogido este cuadro para colgarlo de la pared de la habitación que antecede a la "cárcel» de Vera, y donde ésta es violada por Zeca disfrazado de tigre. Realidad y ficción unidas por una pintura: Zeca ha hecho lo que el organista pintado hubiera deseado hacer: poseer a Venus. Como señalan Bussagli y Zuffi,

el organista, al tiempo que toca, se vuelve para observar y admirar el cuerpo de la diosa, o, mejor dicho, un punto en particular, por así decir, el más significativo. De

${ }^{28}$ López Revuelta, José María (2014): «El arte en el cine: Almódovar y La piel que habito». http://www.cineenconserva.com/2014/05/el-arte-en-el-cine-almodovar-y-la-piel.html. [Consultado el 28/5/2020]. 
ese modo, el sonido del órgano se convierte en una metáfora explícita del acuerdo amoroso, pero con aderezos menos filosóficos y claramente más carnales ${ }^{29}$.

El poeta del cuerpo, como lo define Kenneth Clark, repitió en varias ocasiones el tema de Venus y la música, donde en unas ocasiones la diosa se vuelve al espectador sola o acompañada por Cupido; aunque en las numerosas réplicas le suele acompañar un admirador sentado a sus pies, como ocurre en este caso, que toca un órgano y en otras ocasiones tañe un laúd. Para Almodóvar, la presencia de estos cuadros en la casa significa que en ella se cultivaba la belleza, y desde principios del siglo XVI, Venus es la forma ideal de la belleza, desnuda o semidesnuda, sujeta solo a los cambios de gusto de cada época. Pero no es solo la presencia de esos lienzos, sino que en determinados fotogramas del filme, Vera adopta la postura de estas Venus pintadas. Sirva como ejemplo la escena en la que el cirujano y su «creación» hablan de la importancia de la piel:

Vera: ¿Te gusta lo que ves? ¿Hay algo que quieras mejorar?

Robert: No, no quiero mejorar nada.

Vera: ¿Entonces puedo darme por terminada?

Robert: Sí, y puedes presumir de tener la mejor piel del mundo.

Esa piel que el médico ha creado en un laboratorio y que los pintores venecianos recrean con sus pinceles, que pareciera que acariciaran con ellos los cuerpos, evoca las poesías ${ }^{30}$ de Tiziano $^{31}$; un Tiziano que se erigió en uno de los maestros supremos de la Venus Natural ${ }^{32}$. Vera, en diferentes escenas de la película, recuerda esas poesías ticianescas, llamadas así por su capacidad táctil que incita al deseo; su postura su mono de color carne como una segunda piel o como si estuviera realmente desnuda, es una clara exhortación a la herencia veneciana. Las pinturas de Tiziano son la más pura evocación del deseo, y en la película de Almodóvar, el deseo se transforma en obsesión [fotos 14 y 15].

Como escribiera en 1839 el escultor alemán Adolf Hildebrand, «estos dos medios de percibir el mismo fenómeno, no solo tienen una existencia separada de

29 Bussagli, Marco y Zuffi, Stefano (2001): «El siglo Xvi», en Arte y erotismo, Milán, Ed. Electa, p. 92.

${ }^{30}$ Las poesías, son un conjunto de pinturas de tema mitológico, pintadas por Tiziano por encargo del rey de España Felipe II, entre 1553 y 1562. Tiziano pudo haberse inspirado en los lienzos ejecutados por Antonio Allegri da Correggio sobre los amores de los dioses entre 1530 y 1532.

31 También Antonio Allegri da Correggio (1489-1534) ejecutó una serie de pinturas llamadas poesías, donde interpretó los temas mitológicos, a los que dotó de una fuerte carga de erotismo por encargo exprofeso del duque de Mantua, Federico Gonzaga, entre 1530 y 1532. Basadas en la Metamorfosis de Ovidio, constituyen el encargo más importante de sus últimos años.

${ }^{32}$ Clark, Kenneth (1981): El desnudo. Un estudio de la forma ideal, Madrid, Alianza Editorial, p. 126. 

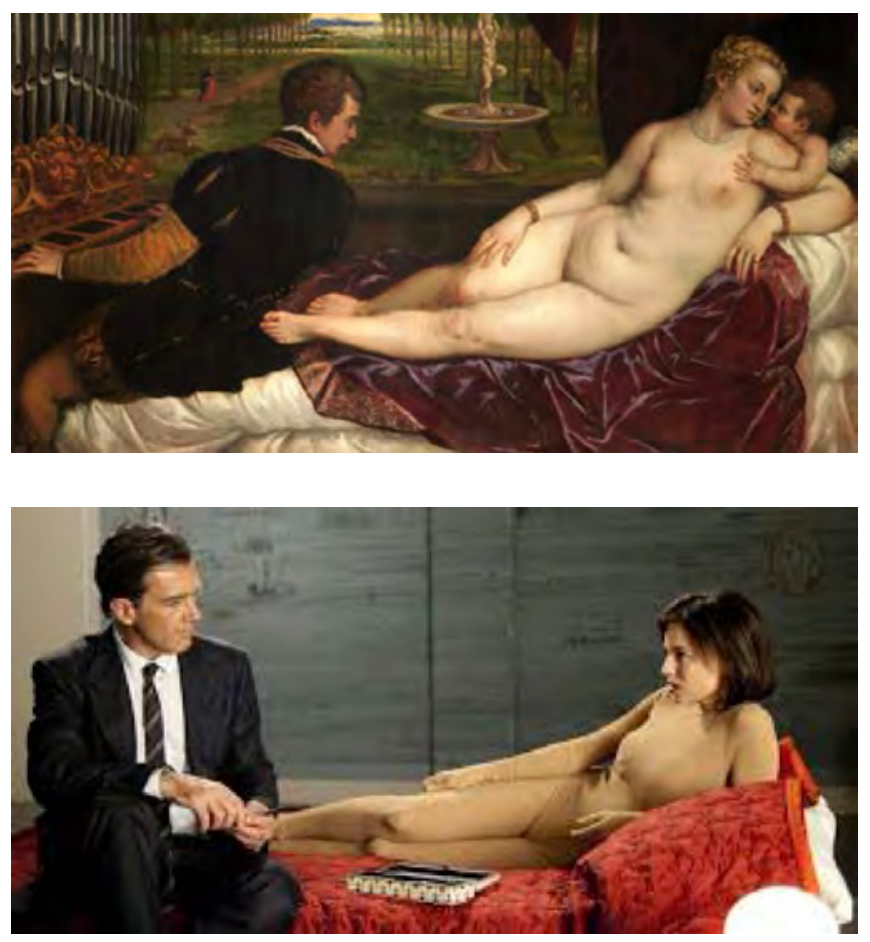

Fotos 14 y 15. Tiziano: Venus recreándose con el amor y la música (c. 1555). Museo del Prado, Madrid (España) y fotograma de La piel que habito (Pedro Almodóvar, 2011).

nuestras facultades de la vista y el tacto, sino que se encuentran unidas en el ojo" ${ }^{33}$. Y lo advierte también Jacques Aumont:

El ojo ve, pero también toca: hay en la visión percepciones ópticas -puramente visuales- y percepciones hápticas -visuales-táctiles-, doble modo que responde, además a otra división, entre Nahsicht (la visión de cerca, la visión corriente de una forma en el espacio vivido, en el que puede uno acercarse y tocar) y Fernsicht (la visión de lejos, la visión de estas mismas formas según las leyes específicas del arte) ${ }^{34}$.

$Y$ este texto nos acerca a otra escena del filme en el que el director manchego recurre a la Venus del espejo del hispalense [foto 16], y es el momento en el que Ledgard recorre con su mirada, a través de una pantalla gigante, como si la aca-

${ }^{33}$ Aumont, Jacques (1996): El ojo interminable. Cine y pintura, Barcelona, Paidós, p. 111.

${ }^{34}$ Idem, pp. 110-111. 

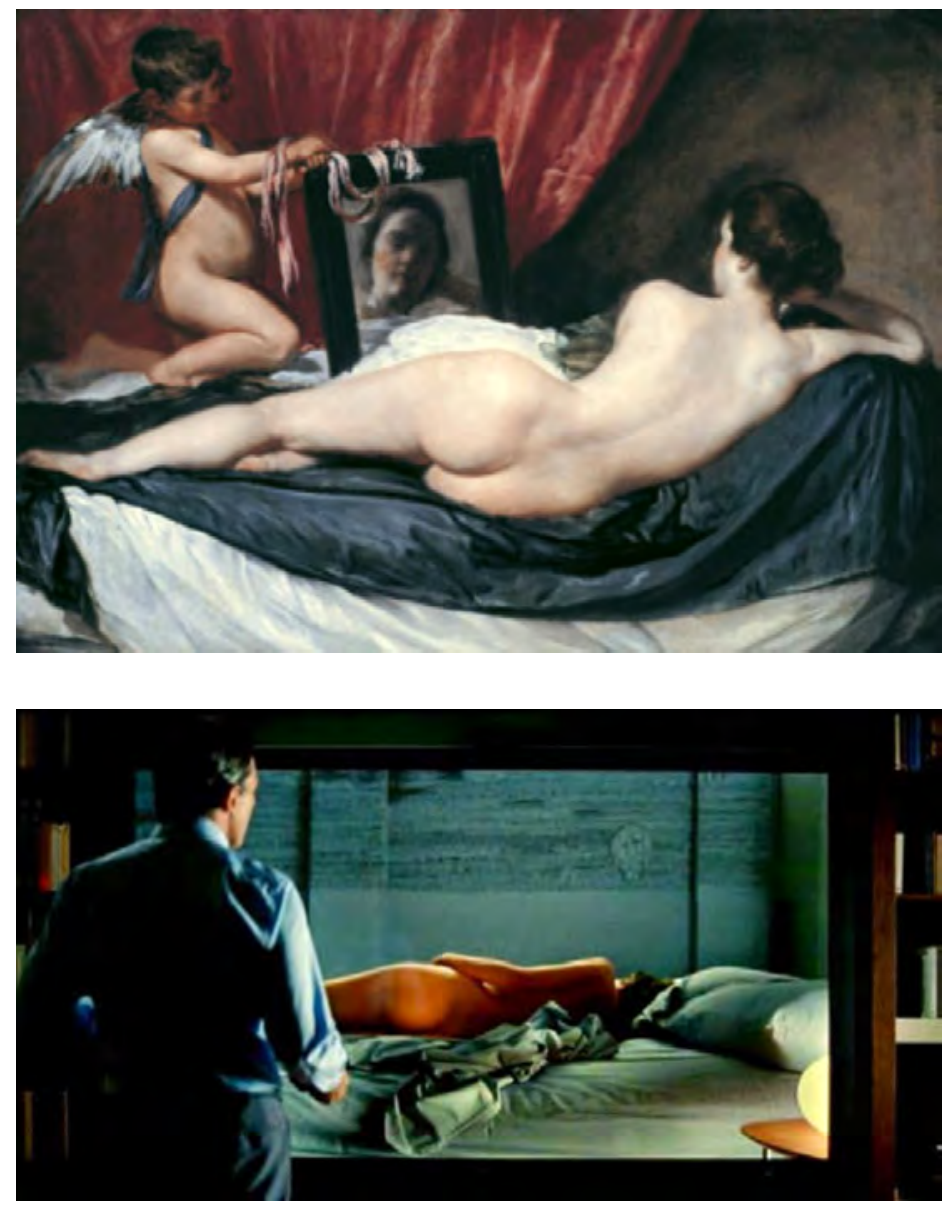

Fotos 16 y 17. Diego Velázquez: Venus del espejo (1647). National Gallery, Londres (Reino Unido) y fotograma de la película La piel que habito (Pedro Almodóvar, 2011).

riciara con las manos, el cuerpo desnudo de espaldas de Vera; una moderna Venus del espejo aunque en este caso los papeles se han invertido. En aquélla es la diosa la que a través del espejo mira -con disimulo- hacia fuera del cuadro al espectador, mientras que en el filme es el médico el que a través de una pantalla mira hacia dentro, tocando con los ojos el cuerpo de Vera, que descansa sobre una cama con sábanas grises como las de la venus velazqueña [foto 17]. Tanto en este caso como en el de las Venus de la Edad Moderna, las figuras se distinguen por su físico perfecto. Vera adopta la postura y el aspecto de Venus porque ambas son objeto de deseo.

Giovanni Pico della Mirandola (1463-1494) advertía en su Commento II que el deseo de amor que despierta la belleza terrenal era, a su vez, de dos tipos opues- 

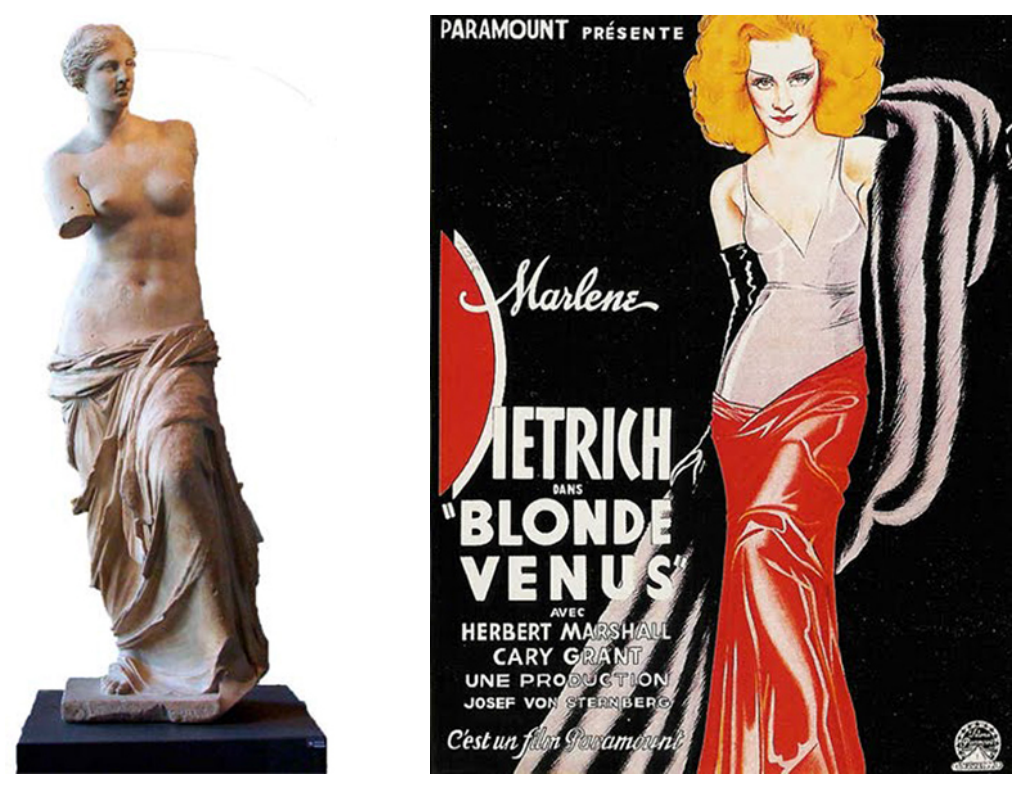

Fotos 18 y 19. Venus de Milo, finales del siglo ir. Museo del Louvre, París (Francia) y cartel de la película Blonde Venus (Josef von Sternberg, 1932).

tos, «de' quali l'úno è bestiale, e l'altro è umano»" ${ }^{35}$. De modo que el instinto puramente sensual

tenderá a situar erróneamente la fuente de la belleza visual en el cuerpo, y a buscar el goce de la belleza sólo en los placeres animales, el amante humano reconocerá que la Venus que aparece vestida con ropas terrenales es una imagen celestial $^{36}$.

Objeto de deseo y prototipo de belleza femenina fue considerada también la Venus (Afrodita) de Milo ${ }^{37}$ [foto 18], a la que en ocasiones también se ha recurrido, de modo que caracterizada como tal aparece Marlene Dietrich en el cartel original de la película Venus rubia (Blonde Venus, Josef von Sternberg, 1932), como si de una moderna Venus de Milo se tratara [foto 19].

35 Wind, Edgar (1998): Los misterios paganos del Renacimiento, Madrid, Alianza Editorial, p. 138.

${ }^{36}$ Idem, p. 138.

${ }^{37}$ Escultura de finales del siglo ir, posible copia helenística de la Afrodita de Capua de Lisipo. Su autor se pone en duda, pero podría ser obra de Alexandros de Antioquía, aunque otros especialistas la han atribuido a Praxiteles, aunque las fechas no coinciden. 


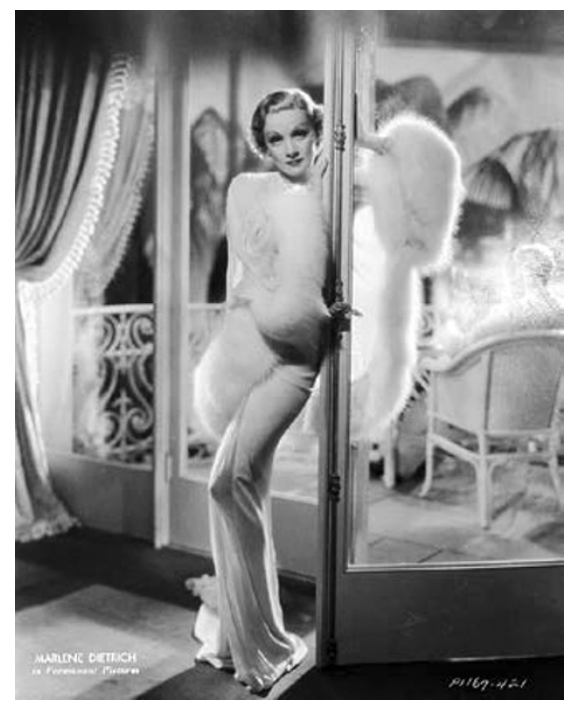

Marlene Dietrich protagoniza la película Blonde Venus (Josef von Sternberg, 1932).

Aunque en este caso tiene brazos, los lleva enfundados en unos largos guantes negros que desaparecen engullidos por el propio color negro del fondo del cartel, dando la impresión de que carece de ellos. Lo mismo ocurre con el brazo izquierdo, disimulado detrás de una larga estola de piel que se prolonga por la espalda y llega hasta el suelo. Aunque la escultura original va semidesnuda, en este caso la actriz viste una delicada ropa interior, tapándose las caderas y piernas con una tela roja. La postura, en ligero contraposto, es idéntica a la de la escultura original, tan solo difieren en la mirada desafiante y guerrera de la Dietrich, frente a la expresión serena, mezcla de tristeza y realismo de la escultura, cuya sensación táctil es importante, pues esos efectos los consiguió el escultor gracias al pulido que le dio al cuerpo de la diosa, que solo lleva puesto un chitón, y que en el cartel se traduce en la sutil y semitransparente ropa que viste la protagonista.

En 1948 de nuevo se acude a ese prototipo cuando Ava Gardner protagoniza Venus era mujer (One Touch of Venus, William A. Seiter, 1948). El argumento gira en torno a Eddie Hatch (Robert Walker), un escaparatista de los almacenes Savory, a quien le encargan descorrer la cortina que tapa una estatua de Venus (Ava Gardner) antes de ser expuesta al público. Cuando la ve queda deslumbrado por su belleza, y en un arrebato de pasión la besa, tornando ésta a la vida inmediatamente ${ }^{38}$. Tras ser

38 Es el mito de Blancanieves (Jacob y Wilhem Grimm, 1812 y Walt Disney, 1937) y el de la Bella durmiente (Charles Perrault, 1697, Jacob y Wilhem Grimm, 1812 y Walt Disney, 1959), según 

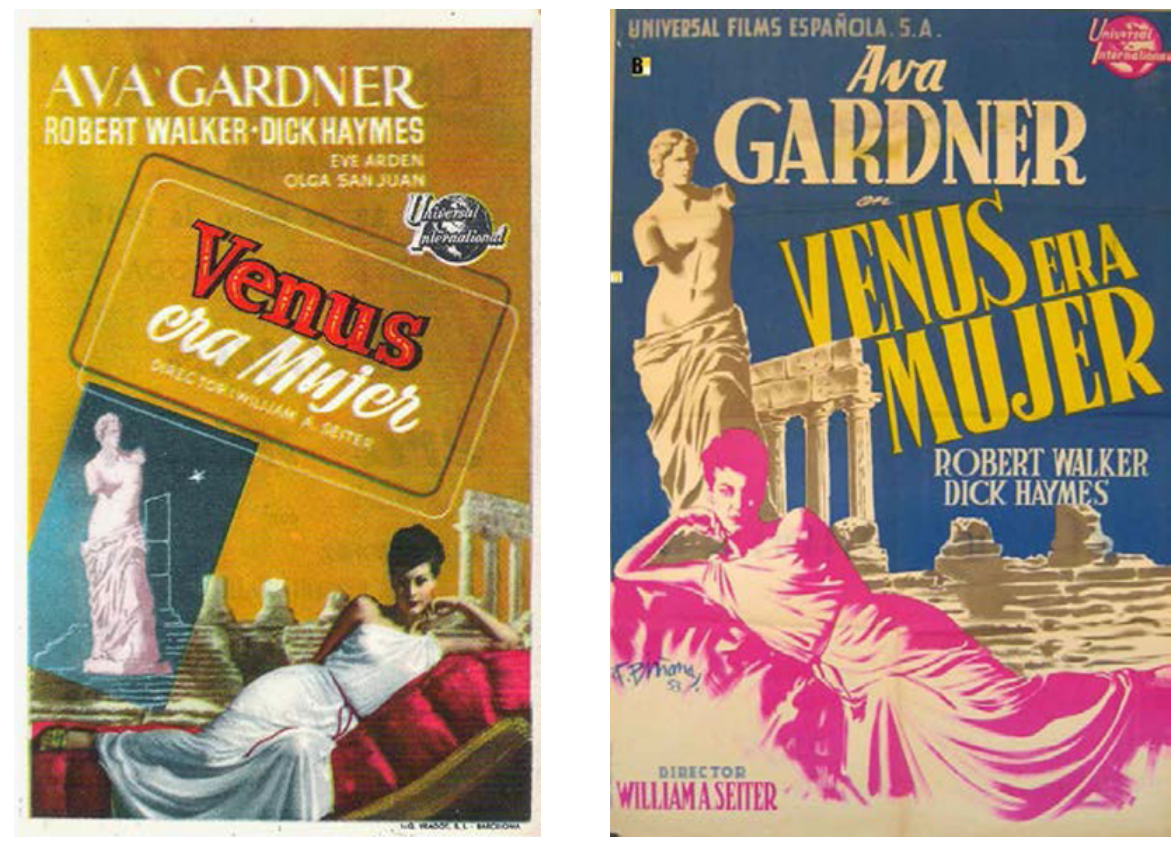

Fotos 20 y 21. Carteles de la película Venus era mujer

(One Touch of Venus, William A. Seiter, 1948).

acusado de ladrón ante la desaparición de la estatua, la policía no cree su explicación, aunque por suerte para él Venus lo ayudará. Si bien es cierto que la escultura que aparece en la película y la Venus de Milo no se parecen en absoluto, sí es verdad que la obra helenística aparece como trasfondo en los carteles en versión espańola que la publicitan [fotos 20 y 21]. Incluso, en algún fotograma de la película la propia Ava-Venus sostiene un facsímil de ella en sus manos, a la que mira embelesada, y en otras ocasiones adopta su pose, recordando una Venus Victrix, victoriosa, como la labrada por Antonio Canova a principios del siglo XviII. Ni Marilyn Monrroe pudo escapar de la atracción de la diosa encontrada en la isla de Milo el 8 de abril de $1820^{39}$, y como tal fue fotografíada ${ }^{40}$.

las versiones cinematográficas de Disney, pero al revés. En los cuentos el príncipe besa a la princesa y ésta revive; en este caso el joven besa a la estatua y ésta toma vida.

39 Etienne, Roland y Françoise (1998): La antigua Grecia. Historia de la Arqueología Helenistica, Barcelona, Ediciones B.S.A., pp. 140-143.

${ }^{40}$ Marcos, Ana: «En los zapatos de Marilyn Monroe». El País Semanal. Madrid, 6 de julio de 2012. https://elpais.com/cultura/2012/07/05/actualidad/1341491231_548681.html. [Consultado el 30/5/2020]. 


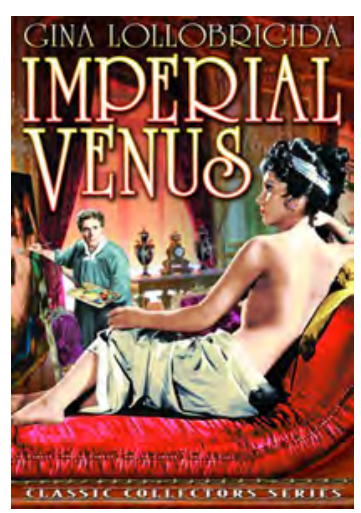

Foto 22. Cartel de la película Imperial Venus (Venere Imperiale, Jean Delannoy, 1962).

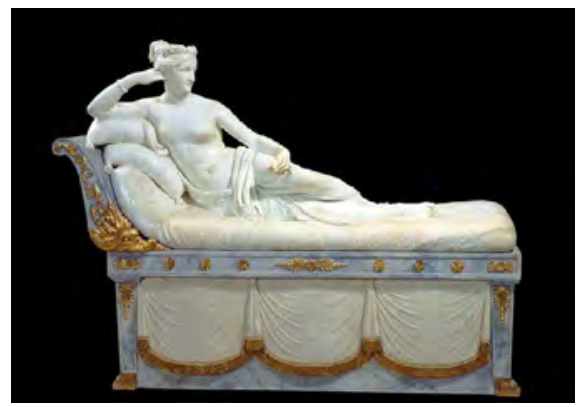

Fotos 22. Antonio Canova: Paulina Bonaparte como Venus Victrix, Galería Borghese, Roma (Italia).

Y como Venus Victrix ${ }^{41}$ [foto 22], la victoriosa, también aparece Gina Lollobrigida en el cartel de la película Venus Imperial (Venere Imperiale, Jean Delannoy, 1962), donde da vida a la hermana de Napoleón Bonaparte. El retrato de Paulina, realizado por el escultor Antonio Canova - papel interpretado por Gianni Santuccio-, la versiona como la victoriosa, por eso lleva en la mano la manzana dorada relacionada con el relato mitológico del Juicio de Paris. La figura semidesnuda de la diosa, de tamaño natural, viste solo un chitón que le tapa caderas, pubis y muslos, apoya la cabeza en la mano derecha y reposa el cuerpo sobre un colchón con dos almohadones, a modo de un chaise longe de estilo imperio, a imitación del mobiliario romano [foto 23]. La escultura, de alguna manera, pareciera pretender rivalizar y revitali-

${ }^{41}$ Antonio Canova, 1804-1808. Galería Borghese, Roma. 

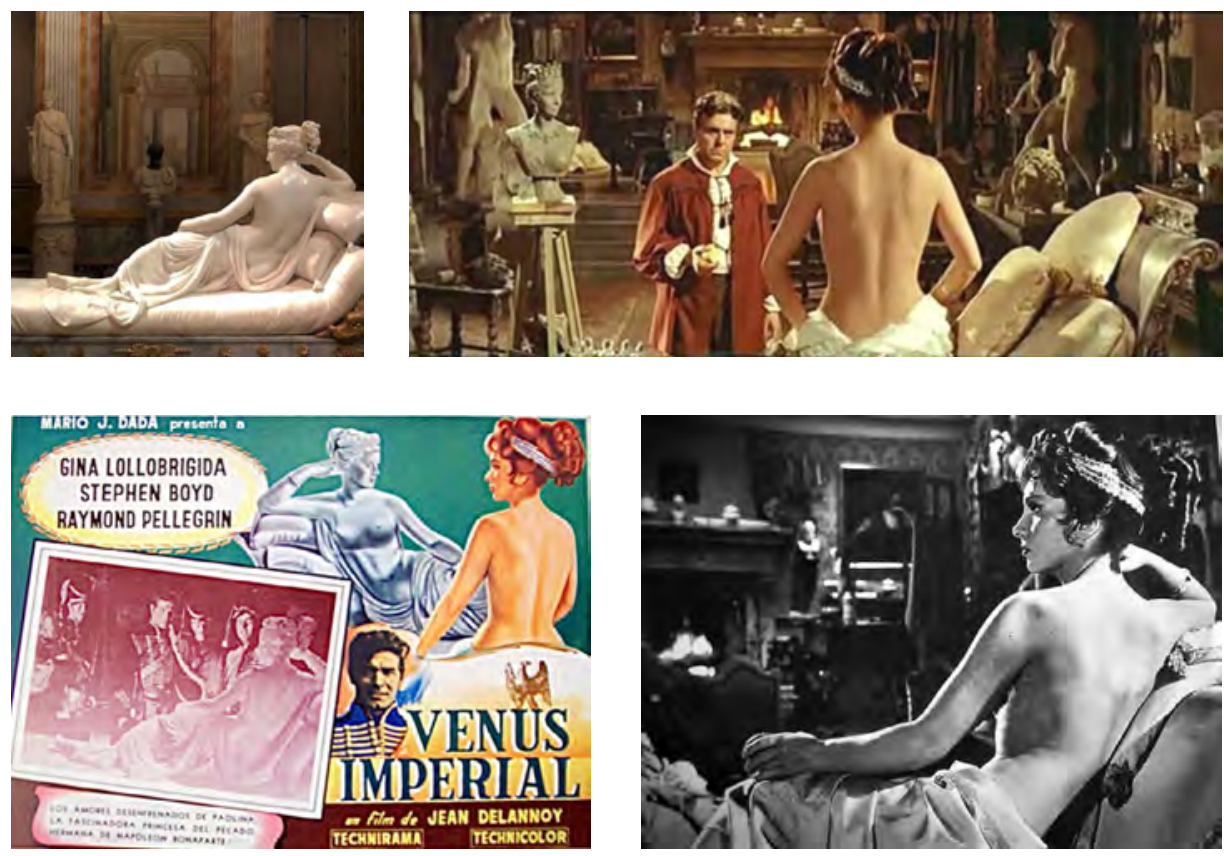

Fotos 24 y 25. Antonio Canova: Paulina Bonaparte como Venus Victrix, Galería Borghese, Roma (Italia) y cartel y escenas de Venus Imperial (Venere Imperiale, Jean Delannoy, 1962).

zar la moda de las venus recostadas, de larga tradición desde el Renacimiento. Es de sobra conocido cómo Canova trataba al mármol, «con mimo [...] en cuyos efectos de morbidez, brillo y transparencia pensaba sin duda al crear sus modelos ${ }^{42}$. La película recrea la ajetreada vida de la joven hermana del militar francés, versionándose en una de las escenas de la película el momento en el que está posando para el artista de Possagno, imitando la postura del modelo esculpido y, aunque inicialmente tenía que ser representada vestida como Diana, la retratada insistió que tenía que ser como Venus y semidesnuda [fotos 24 y 25].

Y, finalmente, de la Venus Victrix llegamos a la Victoria de Samotracia ${ }^{43}$ [foto 26], a la que Audrey Hepburn da vida en la película Una cara con ángel (Funny Face, Stanley Donen, 1957), cuyo argumento gira en torno a un fotógrafo de una

42 Sobrino González, Miguel (marzo 2020). «Antonio Canova. El mármol encarnado», Descubrir el Arte, año xxi, n. ${ }^{\circ} 253$, p. 84.

43 Aunque no todos los especialistas están de acuerdo, se cree que su autor pudo ser Pythocritos de Lindos, y quizás encargada por Demetrio Poliocete, un general macedonio que había ganado a comienzos del siglo III a.C. una batalla naval a los chipriotas. De escuela rodia, hay quie- 

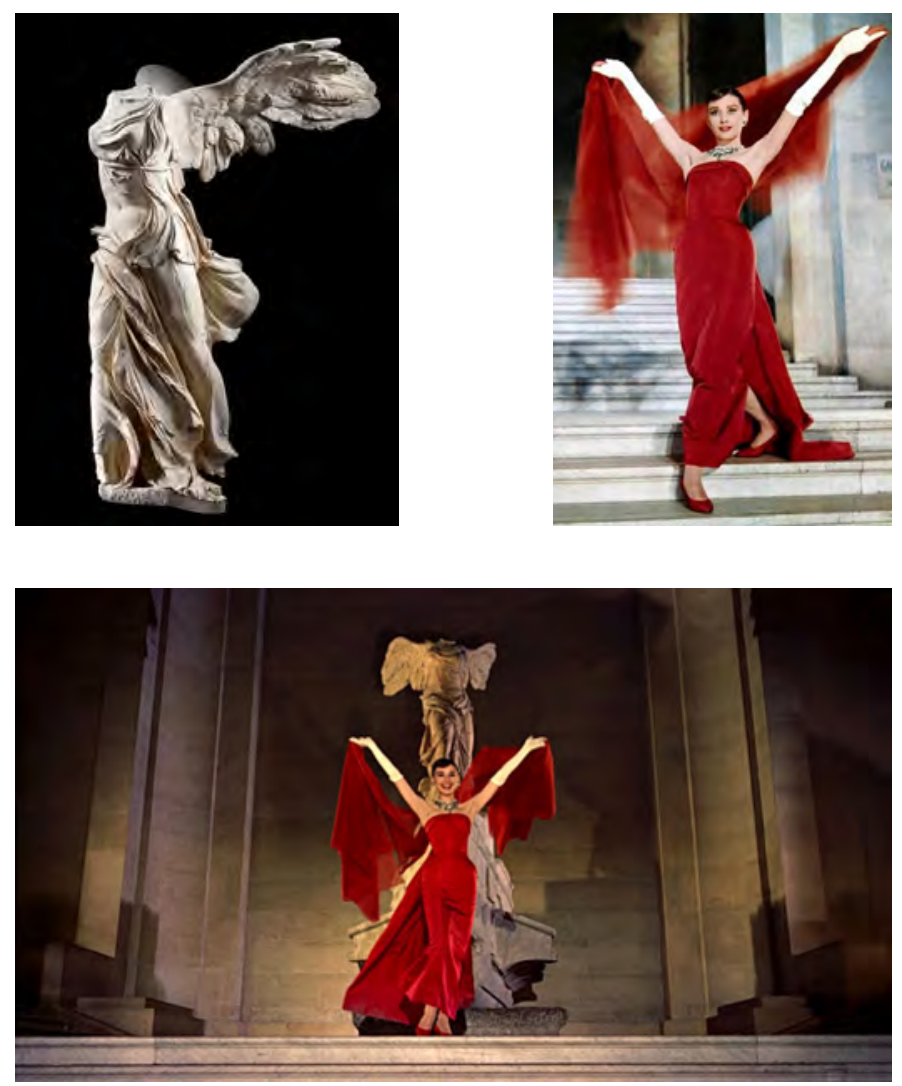

Fotos 26, 27 y 28. Victoria de Samotracia, siglo III a.C. Museo del Louvre, París (Francia) y fotogramas de la película Una cara con ángel (Funny Face, Stanley Donen, 1957).

importante revista de moda, Dick Avery (Fred Astaire), que busca una modelo. En su búsqueda llega a una librería de Nueva York, y allí descubre a una joven dependienta, Jo Stockton (Audrey Hepburn), que reúne todas las cualidades que él buscaba, por lo que decide convertirla en una modelo americana en París.

Y como una moderna Victoria alada, en una de las escenas de la película, vemos a la actriz descendiendo - casi volando- por la escalera Daru, situada a la entrada del Museo del Louvre de París, teniendo como telón de fondo la escultura que con su pose imita [fotos 27 y 28].

nes le encuentran parecido con el estilo de las esculturas externas del Altar de Zeus en Pérgamo. Si eso fuera cierto habría que cuestionarse su fecha de realización, ya que el altar es un siglo posterior. 

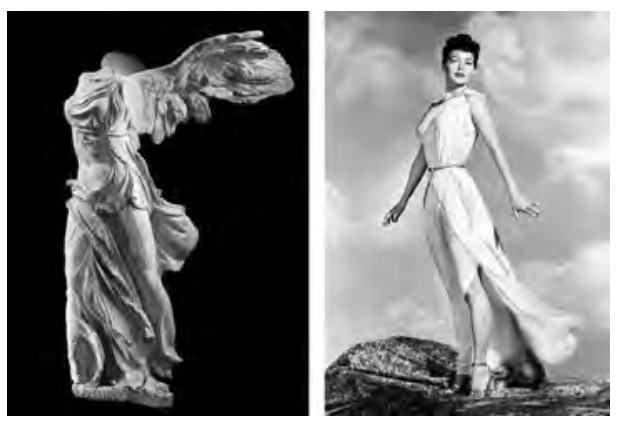

Foto 29. Ava Gardner posando como la Victoria de Samotracia.

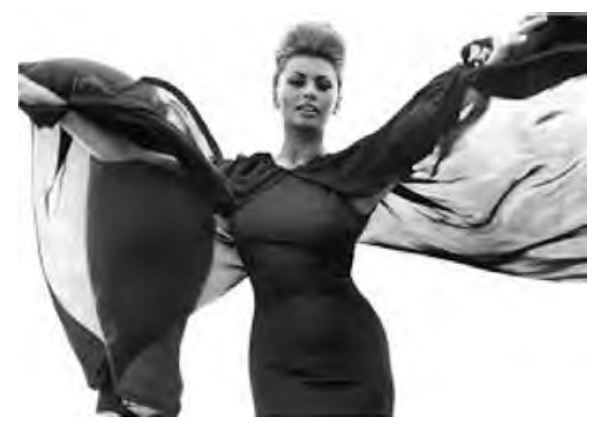

Foto 30. Bert Stern: Sofía Loren como la Victoria de Samotracia. Revista Vogue, 1962.

La diosa de la Victoria viste un fino chitón y un manto que se enrolla sobre el muslo derecho, adhiriéndose al cuerpo y dejando traslucir su anatomía. Esos paños agitados por una violenta ráfaga de aire generan un intenso dramatismo, muy característico de la escuela rodia, a la que la estatua se adscribe ${ }^{44}$. Audrey Hepburn, por el contrario, viste un ceñido traje rojo, en forma de tubo, y es ella la que en su descenso genera el movimiento que hace que su chal rojo se hinche, como las velas de un barco, y su traje se pegue al cuerpo, en clara alusión a la escultura que preside la escalinata en la que está posando.

También Ava Gardner posó como la Victoria alada en una escena de la película Venus era mujer (1948) [foto 29], así como Sofía Loren, que lo hizo para la cámara del fotógrafo norteamericano Bert Stern, para la revista de moda Vogue en 1962 [foto 30], quien con su fotografía nos recuerda las palabras que Nicómaco le dijo a un ignorante que pretendía censurar la Helena pintada por Zeuxis: «Toma mis ojos y la verás como una diosa» ${ }^{45}$.

ReCibido: mayo de 2020; ACEPTADo: junio de 2020

44 Winckelmann, Johann Joachim (1987): Reflexiones sobre la imitación del arte griego en la pintura y la escultura, Barcelona, Nexos, p. 35. «Toda la indumentaria exterior de la mujer griega era de un ligerísimo tejido, y es por ello por lo que se la llamaba péplum, es decir, velo».

${ }^{45}$ Idem, p. 18. 
